\title{
Preparation, characterization and crystal structure of dinuclear zinc(II) carboxylate complex with 1-(pyridin-4-yl)ethanone and 4-methylbenzoate based ligands
}

\author{
Efdal Cimen ${ }^{1}$, Ilkay Gumus 2,*, Omer Celik ${ }^{3}$, Ebru Keskin ${ }^{4}$ and Hakan Arslan ${ }^{2}$ \\ ${ }^{1}$ Department of Chemistry and Chemical Process Technology, Kars Vocational School, Kafkas University, Kars, TR-36100, Turkey \\ 2 Department of Chemistry, Faculty of Arts and Science, Mersin University, Mersin, TR-33344, Turkey \\ ${ }^{3}$ Science and Technology Applied and Research Center, Dicle University, Sur, Diyarbakir, TR-21280, Turkey \\ ${ }^{4}$ Advanced Technology Research and Application Center, Mersin University, Mersin, TR-33343, Turkey \\ * Corresponding author at: Department of Chemistry, Faculty of Arts and Science, Mersin University, Mersin, TR-33344, Turkey. \\ Tel.: +90.324.3610001/4559. Fax:+90.324.3610047. E-mail address: ilkav.gumus@mersin.edu.tr (I. Gumus).
}

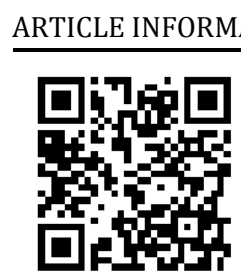

DOI: 10.5155/eurjchem.7.4.448-453.1509

Received: 13 November 2016

Accepted: 03 December 2016

Published online: 31 December 2016

Printed: 31 December 2016

\section{KEYWORDS}

\section{Synthesis}

Zinc complex

Zinc carboxylate

Crystal structure

Centrosymmetric

Dinuclear zinc(II) complex

\section{Introduction}

The zinc ion is of essential importance for biological processes due to the presence of zinc-containing enzymes in biological systems. These enzymes can contain one, two or three zinc ions at the active binding sites, further the two zinc ions can connected to each other via the $\mathrm{Zn} \cdots \mathrm{Zn}$ bond, and the distance between them are generally in the range of 3.0-3.5 $\AA$ [1-6].

Zinc compounds supported by carboxylate ligands which structurally similar to zinc enzyme, are of great interest owing to their role in biochemical systems [7-11]. At the same time, zinc carboxylates are attracting attention as highly active catalysts for the polymerization or copolymerization of a wide range of organic monomers [12-15].

Carboxylates constitute an important class of ligands in the formation of coordination compounds [16-24]. Because ambidentate nature of their can display a wide variety of metal coordination modes such as monodentate terminal, chelating, bidentate bridging and monodentate bridging modes (Figure $1)$, which lead to several types of compounds [25-27]. The nature of the bridging environment between adjacent zinc ions varies significantly in the structures and often several different environments exist within the same structure.<smiles>[M]OC([R])=O</smiles>

anti monodentate terminal<smiles></smiles>

$$
\begin{aligned}
& \text { monodentate } \\
& \text { terminal }
\end{aligned}
$$

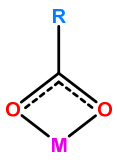

symmetric chelating<smiles></smiles>

asymmetric chelating

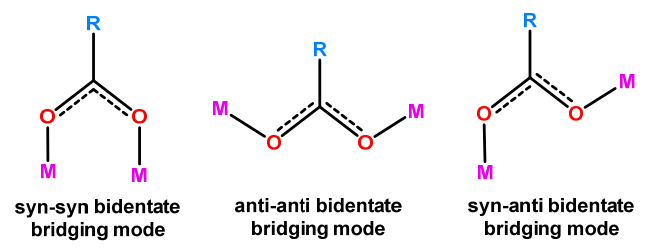

Figure 1. Carboxylate binding modes in metal complexes. 


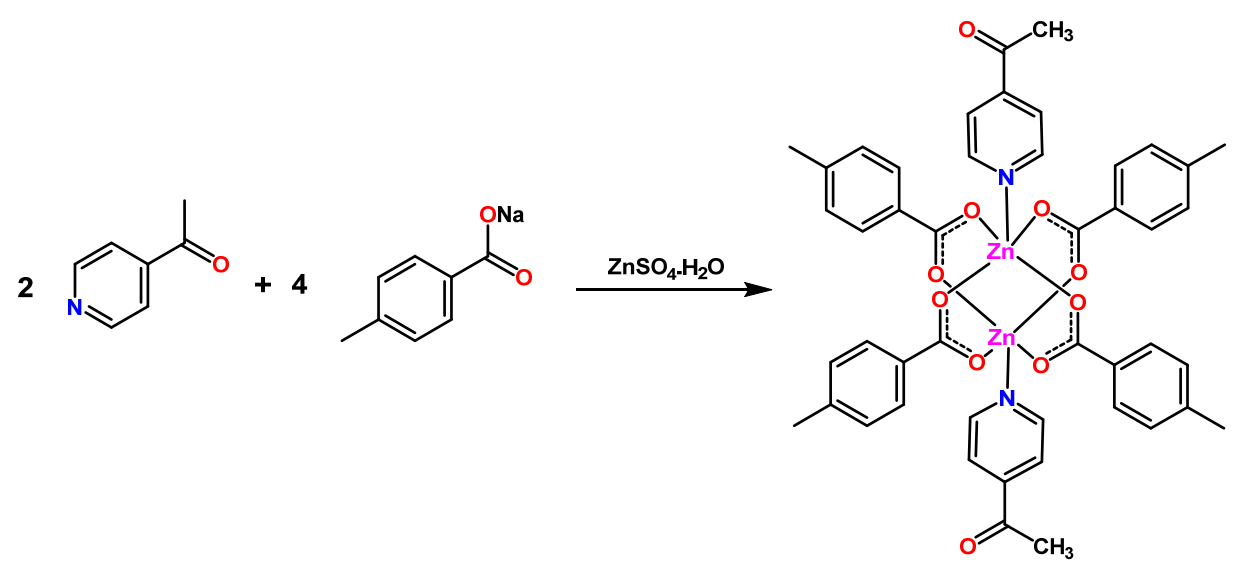

Scheme 1

Here, we report the synthesis and characterization of dinuclear zinc(II) complex, tetrakis( $\mu$-4-methylbenzoato$\left.\kappa^{2} O: 0\right]$-bis[ $\left(\mu\right.$-acetylpyridine- $\left.\kappa \mathrm{N}^{1}\right)$-zinc(II), supported by carboxylate ligands. Structural characterization of complex was achieved by single crystal X-ray diffraction technique.

\section{Experimental}

\subsection{Instrumentation}

Infrared measurement was recorded in the range 400$4000 \mathrm{~cm}^{-1}$ on a Perkin Elmer Spectrum 100 series FT-IR/FIR/ NIR Spectrometer Frontier, ATR Instrument. The NMR spectra were recorded in DMSO- $d_{6}$ solvent on Bruker Avance III 400 MHz NaNoBay FT-NMR spectrophotometer using tetramethyl silane as an internal standard. Crystallographic measurements of the compound were carried out at 296(2) K using a Bruker APEX-II CCD area-detector diffractometer. The intensity data were collected using graphite monochromated Mo-Ko radiation, $\lambda=0.71073 \AA$. Absorption corrections were applied with the program SADABS [28]. The structure was solved by direct methods SHELXS-97 [29], and refined by full-matrix leastsquares techniques on $F^{2}$ using SHELXL-97 with refinement of $F^{2}$ against all reflections. Hydrogen atoms were constrained by difference maps and were refined isotropically, and all nonhydrogen atoms were refined anisotropically. The molecular structure plots were prepared using PLATON [30] and ORTEP III [31]. The anisotropic thermal parameters and structure factors (observed and calculated), full list of bond distances, bond angles and torsional angles are given in supplementary materials. The geometric special details: all e.s.d.'s (except the e.s.d. in the dihedral angle between two l.s. planes) are estimated using the full covariance matrix. The cell e.s.d.'s are taken into account individually in the estimation of e.s.d.'s in distances, angles and torsion angles; correlations between e.s.d.'s in cell parameters are only used when they are defined by crystal symmetry. An approximate (isotropic) treatment of cell e.s.d.'s is used for estimating e.s.d.'s involving l.s. planes.

\subsection{Synthesis}

A solution of 1-(pyridin-4-yl)ethanone $(0.61 \mathrm{~g}, 5 \mathrm{mmol})$ in $\mathrm{H}_{2} \mathrm{O}(10 \mathrm{~mL})$ and sodium 4-methylbenzoate $(1.58 \mathrm{~g}, 10 \mathrm{mmol})$ in $\mathrm{H}_{2} \mathrm{O}(250 \mathrm{~mL})$ was added dropwise $\mathrm{ZnSO}_{4} \mathrm{H}_{2} \mathrm{O}(0.90 \mathrm{~g}, 5$ $\mathrm{mmol}$ ) in $\mathrm{H}_{2} \mathrm{O}$. The reaction mixture was stirred for $30 \mathrm{~min}$ in room temperature. The mixture was filtered and crystals were formed within five days at room temperature (Scheme 1).

Tetrakis $\left(\mu-4\right.$-methylbenzoato- $\left.\kappa^{2} 0: 0^{\prime}\right)-$ bis $[(\mu$-acetylpyridi ne- $\mathrm{N}^{1}$ )-zinc(II)]: FT-IR (ATR, $\left.v \mathrm{~cm}^{-1}\right): 1630 v(\mathrm{C}=\mathrm{C})_{\text {ring, }} 1562$ $v\left(\mathrm{COO}^{-}\right)_{\text {asym }}, 1401 v\left(\mathrm{COO}^{-}\right)_{\text {sym }}, 1032 v(\mathrm{C}-\mathrm{N})_{\mathrm{py}}, 2920 v(\mathrm{C}-\mathrm{H})_{\text {aliphatic }}$
$475 v(\mathrm{Zn}-\mathrm{N}) .{ }^{1} \mathrm{H}$ NMR (400 MHz, DMSO- $\left.d_{6}, \delta, \mathrm{ppm}\right): 8.82$ (dd, $4 \mathrm{H}, \mathrm{Ar}-\mathrm{H}$ ), 7.85 (s, 4H, Ar-H), 7.83 (ddd, 8H, Ar-H), 7.21 (dd, $8 \mathrm{H}, \mathrm{Ar}-\mathrm{H}), 2.63$ (s, 6H, CO-CH $\left.\mathrm{CH}_{3}\right), 2.34$ (s, $12 \mathrm{H}, \mathrm{Ph}^{\left.-\mathrm{CH}_{3}\right) .}{ }^{13} \mathrm{C} \mathrm{NMR}$ $\left(100 \mathrm{MHz}, \mathrm{DMSO}-d_{6}, \delta, \mathrm{ppm}\right): 198.08,171.84,150.78,142.65$, $140.62,131.90,129.58,128.46,121.36,26.88,21.02$.

\section{Results and discussion}

The dinuclear $\mathrm{Zn}$ (II) complex was obtained from the reaction with $\mathrm{ZnSO}_{4} \cdot \mathrm{H}_{2} \mathrm{O}$ metal salt of 1-(pyridin-4-yl) ethanone and sodium 4-methylbenzoate compounds in water at room temperature and characterized by various spectroscopic techniques and also by X-ray crystallography. All the characterization data of the synthesized complex confirm the proposed structures. Scheme 1 outlines the synthesis of the complex.

FT-IR spectral analysis confirms the presence of characteristic groups in the $\mathrm{Zn}(\mathrm{II})$ complex. The main vibrational bands of the complex are given in the experimental section. The stretching vibrations of $v(\mathrm{CH})$ groups are observed in the region above $3000 \mathrm{~cm}^{-1}$. The stretching vibrations of aliphatic $v(\mathrm{CH})$ groups of 1-(pyridin-4-yl)ethanone are at $2952 \mathrm{~cm}^{-1}$. The $v(\mathrm{C}=0)$ stretching vibration band belong to 1 -(pyridin-4yl)ethanone ligands are showed at 1672 and $1707 \mathrm{~cm}^{-1}$, respectively.

The potential carboxylate binding modes for zinc complex can determine by infrared spectroscopy. For the IR spectra of carboxylates, the stretching vibrations of the carboxylate group $v_{\text {asym }}(\mathrm{COO})$ and $v_{\text {sym }}(\mathrm{COO})$ are characteristic. But, stretching vibrations belong to aromatic rings in both benzoate and $\mathrm{N}$-donor ligands can observe in the same region of the spectrum as the stretching vibrations of the carboxylate group. The value of $\Delta_{v}\left[v_{\text {asym }}(\mathrm{COO})-v_{\text {sym }}(\mathrm{COO})\right]$ can provide structural insight into the coordination mode of the carboxylate group [32,33]. These values are applied to assign the type of the carboxylate coordination in inorganic complexes [34-38].

The $\Delta$ values determined from the IR spectra of the synthesized zinc complex. The synthesized complex has stretching $v_{\text {asym }}(\mathrm{COO})$ at $1562 \mathrm{~cm}^{-1}$ and $v_{\text {sym }}(\mathrm{COO})$ at $1401 \mathrm{~cm}^{-1}$ (Figure 1). The experimental $\Delta_{v}$ value $161 \mathrm{~cm}^{-1}$ which suggested, that zinc complex forms the paddle-wheel centrosymmetric dimmer with four syn-syn carboxylato bridges [39]. In the synthesized dinuclear zinc complex, the $\Delta_{v}$ value $\left(161 \mathrm{~cm}^{-1}\right)$ is consistent with the coordination modes of the carboxylate group observed in the complex.

The NMR spectrum of complex was recorded in DMSO- $d_{6}$. The NMR data of the obtained complex is given in the experimental section and are consistent with the structural results. 


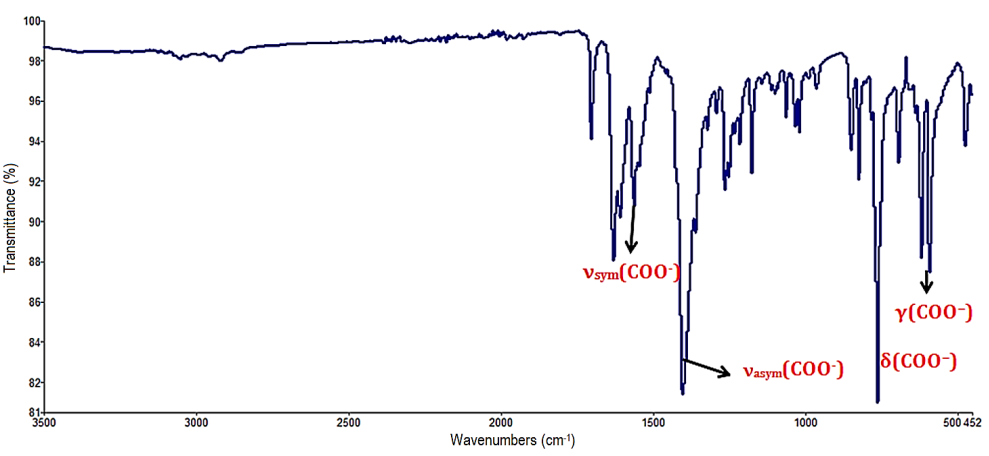

Figure 1. Infrared spectrum of the zinc complex.
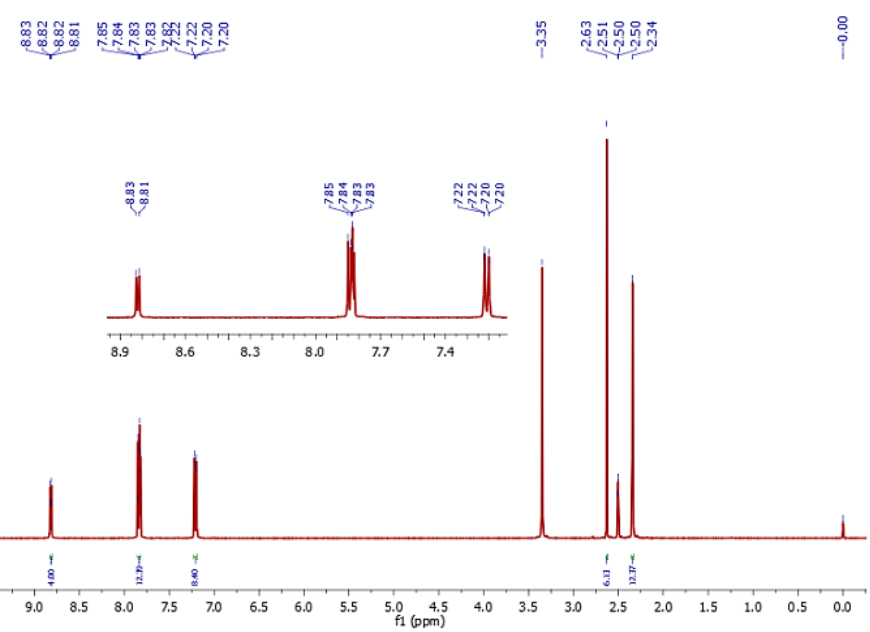

Figure 2. ${ }^{1} \mathrm{H}$ NMR spectrum of the zinc complex.

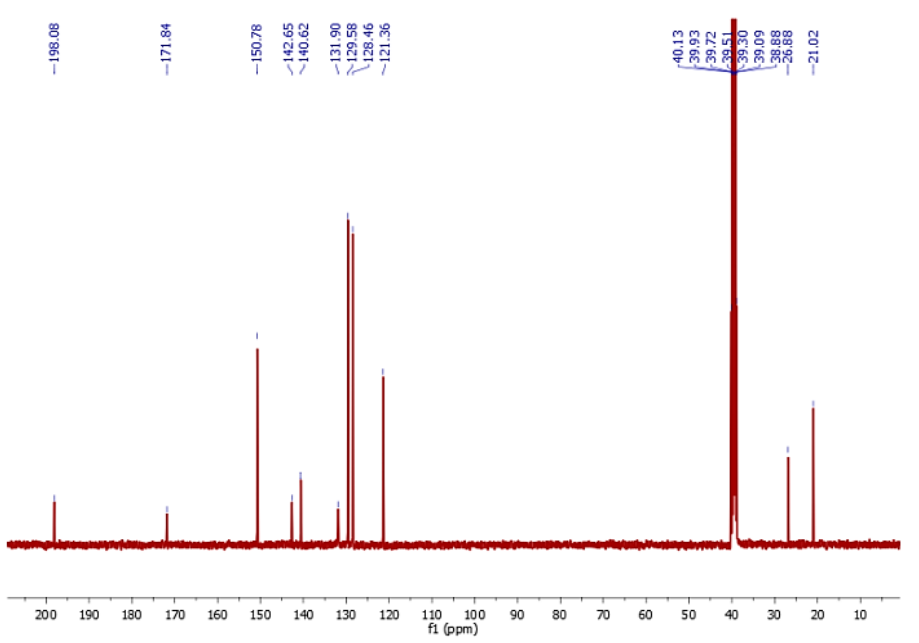

Figure $3 .{ }^{13} \mathrm{C}$ NMR spectrum of the zinc complex.

The signals belong to the $\mathrm{Ph}-\mathrm{CH}_{3}$ and $\mathrm{CO}-\mathrm{CH}_{3}$ groups of the ligands were observed in the most upfield as a singlet at $\delta 2.34$ and $2.63 \mathrm{ppm}$ in the ${ }^{1} \mathrm{H}$ NMR spectrum, respectively. The protons of the aromatic rings are observed in the region approximately at $\delta \sim 7-8 \mathrm{ppm}$ (Figure 2). The ${ }^{13} \mathrm{C}$ NMR spectra displayed signals corresponding to the characteristic quarternary carbonyl and carboxylate groups at $\delta 198.08$ and 171.84 ppm, respectively (Figure 3).
The structure of complex was confirmed by the result of single crystal X-ray diffraction determination. The synthesized dinuclear zinc complex has a paddle-wheel type structure with two 1-(pyridin-4-yl)ethanone ligands at axial positions and in each case there are four carboxylate ligands bridging the two zinc centers (Figure 4). Asymmetric unit contains half of whole molecule, and there is an inversion center in the middle of $\mathrm{Zn}$ Zn bond. 
Table 1. Crystallogrphic data for the Zn(II) complex.

\begin{tabular}{|c|c|}
\hline Parameters & {$\left[\mathrm{Zn}_{2}\left(\mathrm{C}_{8} \mathrm{H}_{7} \mathrm{O}_{2}\right)_{4}\left(\mathrm{C}_{7} \mathrm{H}_{7} \mathrm{NO}\right)_{2}\right]$} \\
\hline Empirical formula & $\mathrm{C}_{23} \mathrm{H}_{21} \mathrm{NO}_{5} \mathrm{Zn}$ \\
\hline Formula weight & 456.78 \\
\hline Temperature (K) & $296(2)$ \\
\hline Crystal system & Monoclinic \\
\hline Space group & $\mathrm{P} 2{ }_{1} / \mathrm{c}$ \\
\hline a, $(\AA)$ & $10.4827(3)$ \\
\hline b, $(\AA)$ & $8.6141(2)$ \\
\hline$c,(\AA)$ & $24.7582(6)$ \\
\hline$\beta,\left(^{\circ}\right)$ & $101.0660(10)$ \\
\hline Volume $\left(\AA^{3}\right)$ & $2194.07(10)$ \\
\hline$Z$ & 4 \\
\hline $\mathrm{D}_{\text {calc }}\left(\mathrm{g} \mathrm{cm}^{-1}\right)$ & 1.383 \\
\hline $\mathrm{M}\left(\mathrm{mm}^{-1}\right)$ & 1.152 \\
\hline$F(000)$ & 944.0 \\
\hline Crystal size $\left(\mathrm{mm}^{3}\right)$ & $0.25 \times 0.25 \times 0.25$ \\
\hline Radiation & $\operatorname{MoK} \alpha(\lambda=0.71073)$ \\
\hline $2 \Theta$ range for data collection $\left({ }^{\circ}\right)$ & $3.96-58.92$ \\
\hline Index ranges & $-14 \leq h \leq 14,-10 \leq k \leq 11,-34 \leq l \leq 34$ \\
\hline Reflections collected & 22545 \\
\hline Independent reflections & $5872\left[R_{\text {int }}=0.0388, R_{\text {sigma }}=0.0333\right]$ \\
\hline Data/restraints/parameters & $5872 / 0 / 274$ \\
\hline Goodness-of-fit on $F^{2}$ & 1.048 \\
\hline Final $R$ indexes $(I \geq 2 \sigma(I))$ & $\mathrm{R}_{1}=0.0472, \mathrm{wR}_{2}=0.1470$ \\
\hline Final R indexes (all data) & $\mathrm{R}_{1}=0.0733, \mathrm{wR}_{2}=0.1613$ \\
\hline Largest diff. peak/hole / e $\AA^{-3}$ & $0.44-0.28$ \\
\hline
\end{tabular}

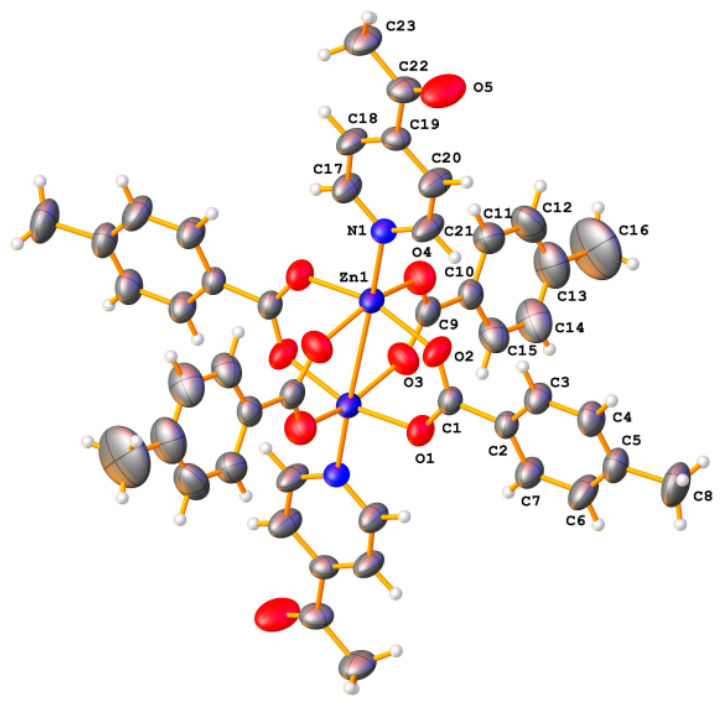

Figure 4. Crystal structure of dinuclear Zn(II) complex.

The each $\mathrm{Zn}$ atom is one nitrogen and four oxygen donor atoms penta-coordinated to form square pyramidal geometry. The paddle-wheel type structure for dinuclear complex is similar with literature [40-42].

The coordination sphere around each $\mathrm{Zn}$ atom in the complex is shown in Figure 5. The details of crystallographic data and structure refinement parameters are summarized in Table 1 . The metal ligand bond distances and angles are listed in Tables 2 and 3. In the geometry of the complex, it is observed that the orientation of the two planes of the 1-(pyridin-4yl)ethanone rings are perpendicular to each other. $\mathrm{Zn}-\mathrm{O}$ bond distances range from 2.0276(13) to 2.0512(15) $\AA$, on an average, they are somewhat longer than values observed for a series of structurally characterised zinc benzoate complexes $[43,44]$. Zn-N bond distance is $2.0397(15) \AA$ which is typical in $\mathrm{Zn}$ (II) complexes, and Zn-Zn distance is 2.9332(4) $\AA$ (Table 2).

The bond lengths of all $\mathrm{C}-\mathrm{O}$ bonds of synthesized $\mathrm{Zn}(\mathrm{II})$ complex (C1-01 1.252(2), C1-02 1.252(2), 03-C9i 1.250(3), 04-C9 1.250(3) $\AA, i: 2-x, 2-y, 2-z)$ are shorter than the normal $\mathrm{C}-\mathrm{O}$ single bond and longer than normal $\mathrm{C}=\mathrm{O}$ double bond. The bond angles of $02^{i}$-Zn1-01, 01-Zn1-N1, 04-Zn1-03, $02{ }^{i}$-Zn1-
04 and 04-Zn1-N1 are 159.84(6), 99.81(6), 159.85(6), $89.29(7)$ and 89.65(7) $(i: 2-x, 2-y, 2-z)$, respectively. The dihedral angle between $\mathrm{Zn} 1-01-02-\mathrm{C} 1$ and $\mathrm{Zn}-03-04-\mathrm{C2}$ planes is $86.33^{\circ}$. The dihedral angles between the planar carboxylate groups 01-02-C1 and 03-04- $\mathrm{C} 2$ are $75.45^{\circ}$.

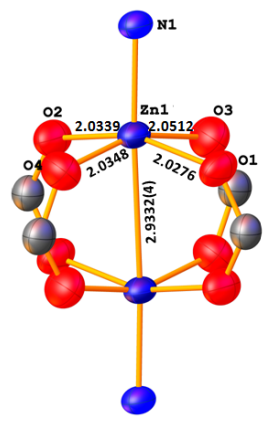

Figure 5. The coordination sphere around zinc atom in the complex. 
Table 2. Selected bond distances for the $\mathrm{Zn}(\mathrm{II})$ complex.

\begin{tabular}{|c|c|c|c|c|c|}
\hline Atom & Atom & Length $(\AA)$ & Atom & Atom & Length $(\AA ̊)$ \\
\hline $\mathrm{Zn} 1$ & $\mathrm{Zn} 1^{i}$ & $2.9332(4)$ & $\mathrm{C} 4$ & C5 & $1.376(3)$ \\
\hline Zn1 & 01 & $2.0276(13)$ & C5 & C6 & $1.380(3)$ \\
\hline Zn1 & $02^{i}$ & $2.0339(14)$ & C5 & C8 & $1.506(3)$ \\
\hline Zn1 & 03 & $2.0512(15)$ & C6 & $\mathrm{C} 7$ & $1.381(3)$ \\
\hline Zn1 & $04^{i}$ & $2.0348(16)$ & C9 & $\mathrm{C} 10$ & $1.497(3)$ \\
\hline Zn1 & N1 & $2.0397(15)$ & C10 & C11 & $1.384(3)$ \\
\hline 01 & C1 & $1.252(2)$ & C10 & C15 & $1.374(3)$ \\
\hline $\mathrm{O} 2$ & $\mathrm{Zn} 1^{i}$ & $2.0338(14)$ & C11 & C12 & $1.376(4)$ \\
\hline $\mathrm{O} 2$ & C1 & $1.252(2)$ & C12 & C13 & $1.377(4)$ \\
\hline $\mathrm{O} 3$ & C9 & $1.250(3)$ & C13 & C14 & $1.370(5)$ \\
\hline 04 & $\mathrm{Zn} 1^{i}$ & $2.0347(15)$ & C13 & C16 & $1.522(4)$ \\
\hline 04 & C9 & $1.250(3)$ & C14 & C15 & $1.371(3)$ \\
\hline 05 & $\mathrm{C} 22$ & $1.201(3)$ & C17 & C18 & $1.373(3)$ \\
\hline N1 & C17 & $1.322(3)$ & C18 & C19 & $1.360(3)$ \\
\hline N1 & $\mathrm{C} 21$ & $1.330(3)$ & C19 & $\mathrm{C} 20$ & $1.374(3)$ \\
\hline C1 & $\mathrm{C} 2$ & $1.495(3)$ & C19 & $\mathrm{C} 22$ & $1.502(3)$ \\
\hline $\mathrm{C} 2$ & C3 & $1.385(3)$ & $\mathrm{C} 20$ & $\mathrm{C} 21$ & $1.369(3)$ \\
\hline $\mathrm{C} 2$ & C7 & $1.373(3)$ & $\mathrm{C} 22$ & C23 & $1.493(3)$ \\
\hline
\end{tabular}

Table 3. Selected bond angles for the Zn(II) complex.

\begin{tabular}{|c|c|c|c|c|c|c|c|}
\hline Atom & Atom & Atom & Angle ( $\left.{ }^{\circ}\right)$ & Atom & Atom & Atom & Angle ( $\left.{ }^{\circ}\right)$ \\
\hline 01 & Zn1 & $\mathrm{Zn} 1^{i}$ & $80.71(4)$ & C9 & 03 & Zn1 & $132.54(15)$ \\
\hline 01 & $\mathrm{Zn} 1$ & $\mathrm{O} 2^{i}$ & $159.84(6)$ & C9 & 04 & $\mathrm{Zn} 1^{i}$ & $121.69(15)$ \\
\hline 01 & $\mathrm{Zn} 1$ & 03 & $85.59(6)$ & C17 & N1 & $\mathrm{Zn} 1$ & $120.79(13)$ \\
\hline 01 & $\mathrm{Zn} 1$ & $04^{i}$ & $89.65(7)$ & C17 & N1 & $\mathrm{C} 21$ & $117.26(17)$ \\
\hline 01 & $\mathrm{Zn} 1$ & $\mathrm{~N} 1$ & $99.81(6)$ & C21 & N1 & Zn1 & $121.93(14)$ \\
\hline $02^{1}$ & $\mathrm{Zn} 1$ & $\mathrm{Zn} 1^{i}$ & $79.15(4)$ & C5 & $\mathrm{C} 4$ & C3 & $121.8(2)$ \\
\hline 021 & $\mathrm{Zn} 1$ & 03 & $88.51(7)$ & $\mathrm{C} 4$ & C5 & C6 & $117.2(2)$ \\
\hline $02^{1}$ & $\mathrm{Zn} 1$ & $04^{i}$ & $89.29(7)$ & $\mathrm{C} 4$ & C5 & C8 & $121.1(2)$ \\
\hline $02^{1}$ & Zn1 & N1 & $100.16(6)$ & C6 & C5 & C8 & $121.7(2)$ \\
\hline 03 & Zn1 & $\mathrm{Zn} 1^{i}$ & $75.57(5)$ & C7 & C6 & C5 & $121.6(2)$ \\
\hline $04^{1}$ & Zn1 & $\mathrm{Zn} 1^{i}$ & $84.34(5)$ & $\mathrm{C} 2$ & C7 & C6 & $120.6(2)$ \\
\hline $04^{1}$ & Zn1 & 03 & $159.85(6)$ & 03 & C9 & 04 & $125.4(2)$ \\
\hline $04^{1}$ & $\mathrm{Zn} 1$ & N1 & $100.90(7)$ & 03 & C9 & C10 & $116.89(19)$ \\
\hline
\end{tabular}

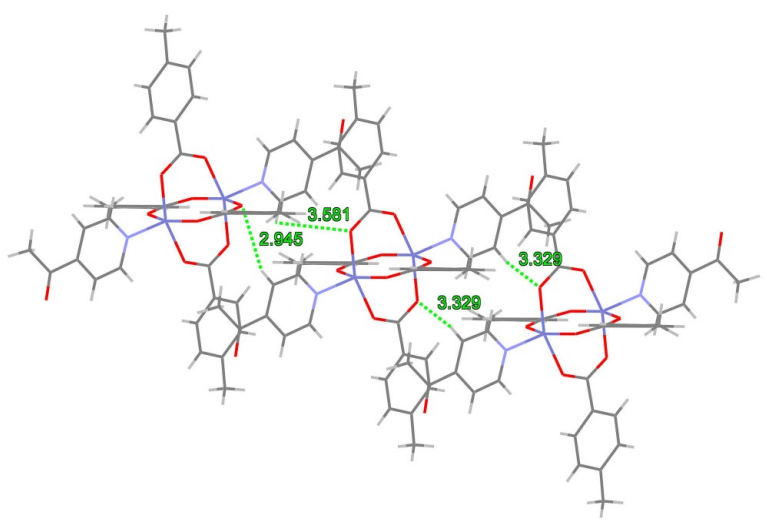

Figure 6. The intermolecular $\mathrm{C}-\mathrm{H} \cdots \mathrm{O}$ interactions of dinuclear $\mathrm{Zn}(\mathrm{II})$ complex. The $\mathrm{C}-\mathrm{H} \cdots \mathrm{O}$ interactions are shown as green dashed lines.

The dinuclear complex present in the crystal lattice of the self-assembly are held together by weak $\mathrm{C}-\mathrm{H} \cdots \mathrm{O}$ interactions. The intermolecular $\mathrm{C}-\mathrm{H} \cdots \mathrm{O}$ (C10-H8 $\cdots 04,3.581 \AA$; $\mathrm{C} 11-$

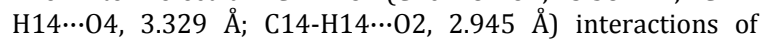
dinuclear Zn(II) complex is shown in Figure 6. The packing diagram of zinc complex is also shown in Figure 7.

\section{Conclusions}

A new class of compound formed by a dinuclear zinc carboxylate complex were prepared and characterized by IR, NMR spectroscopy and single crystal X-ray diffraction. Single crystal analysis and $\Delta$ values determined from the IR spectra revealed that the synthesized zinc complex forms the paddlewheel centrosymmetric dimmer with four syn-syn carboxylato bridges. Also, the dinuclear complex present in the crystal lattice of the self-assembly are held together by weak $\mathrm{C}-\mathrm{H} \cdots \mathrm{O}$ interactions.

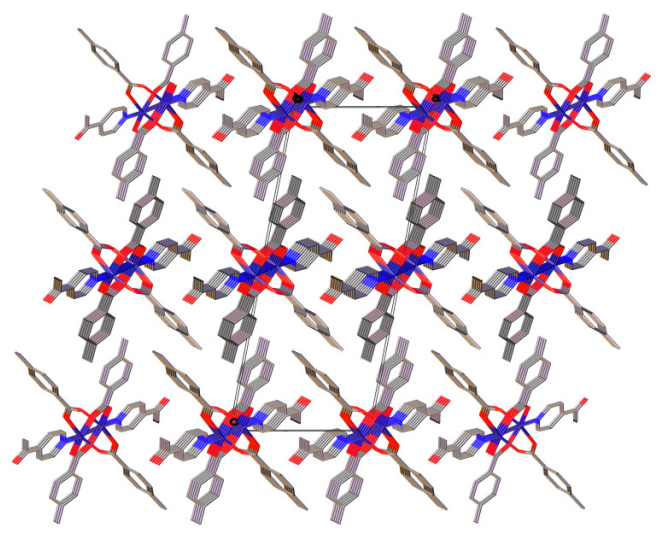

Figure 7. The packing diagram of Zn(II) complex. 


\section{Acknowledgements}

This study was supported by the Research Fund of Mersin University in Turkey with Project Number: 2015-AP4-1162.

\section{Supplementary material}

CCDC-1515549 contains the supplementary crystallographic data for this paper. These data can be obtained free of charge via www.ccdc.cam.ac.uk/data request/cif, or by e-mailing data request@ccdc.cam.ac.uk, or by contacting The Cambridge Crystallographic Data Centre, 12 Union Road, Cambridge CB2 1EZ, UK; fax: +44(0)1223-336033.

\section{References}

[1]. Krezel, A.; Maret, W. Arch. Biochem. Biophys. 2016, 611(1), 3-19.

[2]. Jurowski, K.; Szewczyk, B.; Nowak, G.; Piekoszewski, W. J. Bio. Inorg. Chem. 2014, 19, 1069-1079.

[3]. Lipscomb, W. N.; Strater, N. Chem. Rev. 1996, 96, 2375-2434

[4]. Wilcox, D. E. Chem. Rev. 1996, 96, 2435-2458.

[5]. Strater, N.; Lipscomb, W. N.; Klabunde, T.; Krebs, B. Angew. Chem. Int. Edit. 1996, 35, 2024-2055.

[6]. Steinhagen, H.; Helmchem, G. Angew. Chem. Int. Edit. 1996, 35, 2339 2342.

[7]. Jacobsen, F. E.; Lewis, J. A.; Cohen, S. M. J. Am. Chem. Soc. 2006, 128, 3156-3157.

[8]. Weston, J. Chem. Rev. 2005, 105, 2151-2174.

[9]. Parkin, G. Chem. Rev. 2004, 104, 699-768.

[10]. Horrocks, W. D.; Ishley, J. N.; Whittle, R. R. Inorg. Chem. 1982, 21 , 3265-3269.

[11]. Horrocks, W. D.; Ishley, J. N.; Whittle, R. R. Inorg. Chem. 1982, 21 3270-3274.

[12]. W. Kuran, Principles of Coordination Polymerisation, Wiley, Chichester, chap. 9, 2001

[13]. Coates, G. W.; Moore, D. R. Angew. Chem. 2004, 116, 6784-6806

[14]. Coates, G. W.; Moore, D. R. Angew. Chem. Int. Edit. 2004, 43, 66186639.

[15]. Darensbourg, D. J. Chem. Rev. 2007, 107, 2388-2410.

[16]. Pedireddi, V. R.; Varughese, S. Inorg. Chem. 2004, 43, 450-457.

[17]. Ng, M. T.; Deivaraj, T. C.; Klooster, W. T.; McIntyre, G. J.; Vittal, J. J. Chem-Eur J. 2004, 10, 5853-5859.

[18]. Tong, M. L.; Chen, H. J.; Chen, X. M. Inorg. Chem. 2000, 39, 2235-2238.

[19]. Zhang, Y. S.; Enright, G. D.; Breeze, S. R.; Wang, S. New J. Chem. 1999, 39, 625-628.

[20]. Wang, R.; Jiang, F.; Zhou, Y.; Han, L.; Hong, M. Inorg. Chim. Acta 2004, 358, 545-554.

[21]. Zhu, L. G.; Kitagawa, S.; Miyasaka, H.; Chang, H. C. Inorg. Chim. Acta 2003, 355, 121-127.

[22]. Toh, N. L.; Nagarathinam, M.; Vittal, J. J. Angew. Chem. Int. Edit. 2005, 44, 2237-2041.

[23]. Conerney, B.; Jensen, P.; Kruger, P. E.; Moubaraki, B.; Murray, K. S. Cryst. Eng. Comm. 2003, 5, 454-458.

[24]. Carballo, R.; Covelo, B.; El-Fallah, M. S.; Ribas, J.; Vazquez-Lopez, E. M. Cryst. Growth Des. 2007, 7, 1069-1077.

[25]. Curtiss, A. B. S.; Bera, M.; Musie, G. T.; Powell, D. R. Dalton Trans. 2008, 2717-2724

[26]. Aroraa, H.; Mukherjee, R. New J. Chem. 2010, 34, 2357-2365.

[27]. Zelenak, V.; Vargova, Z. Gyoryova, K. Spectrochim. Acta A 2007, 66, 262-272.

[28]. Bruker, SADABS. Bruker AXS Inc. , Madison, Wisconsin, USA, 2007.

[29]. Sheldrick, G. M. Acta Crystallogr. A, 2008, 64, 112-122.

[30]. Farrugia, L. J. J. Appl. Crystallogr. 1997, 30, 568.

[31]. Morsali, A.; Masoomi. M. Y. Coord. Chem. Rev. 2009, 253, 1882-1905

[32]. Tackett, J. E. Appl. Spectrosc. 1989, 43, 483-489.

[33]. Nakamoto, K. Infrared Spectra of Inorganic and Coordination Compounds, 4th ed. , Wiley, New York, 1986.

[34]. Deacon, G. B.; Phillip, R. J. Coord. Chem. Rev. 1980, 33, 227-250.

[35]. Nakamoto, K. Infrared and Raman Spectra of Inorganic and Coordination Compounds, John Wiley \& Sons, New York, 1997.

[36]. Martini, D.; Pellei, M.; Pettinari, C.; Skelton, B. W.; White, A. H. Inorg. Chim. Acta 2002, 333, 72-82.

[37]. Lewandowski, W.; Kalinowska, M.; Lewandowska, H. Inorg. Chim. Acta 2005, 358, 2155-2166.

[38]. Czakis-Sulikowska, D.; Czylkowska, A. J. Therm. Anal. Calorim. 2007, 90, 681-686.

[39]. Zelenak, V.; Vargova, Z.; Gyoryova, K. Spectrochim. Acta A 2007, 66, 262-272.

[40]. Karmaker, A.; Sarma, R. J.; Baruah, J. B. Inorg. Chem. Commun. 2006, 9, 1169-1172.

[41]. Uhlenbrock, S.; Krebs, B. Angew. Chem. Int. Edit. 1992, 31, 1647-1648.

[42]. Clegg, W.; Little R. I.; Straughan, B. P. J. Chem. Soc., Dalton Trans. 1986, 6, 1283-1288.
[43]. Clegg, W.; Harbron, D. R.; Homan, C. D.; Hunt, P. A.; Little, I. R.; Straughan, B. P. Inorg. Chim. Acta 1991, 186, 51-60.

[44]. Clegg, W.; Harbron, D. R.; Hunt, P. A.; Little, I. R.; Straughan, B. P. Acto Crystallogr. C 1990, 46, 750-753. 